\title{
Design Structure Matrix: A Model Proposal and Implementation on Harbor and Building Design Project
}

\author{
Salman Akram* Jeonghwan Kim** Seungwoo Pi ${ }^{\star \star \star}$ Jongwon Seo ${ }^{\star \star \star *}$
}

\begin{abstract}
Design is an iterative, generative, and multidisciplinary process by its nature. Iteration occurs often in most of the engineering design and development projects including construction. Design iterations cause rework, and extra efforts are required to get the optimal sequence and to manage the projects. Contrary to simple design, isolation of the generative iterations in complex design systems is very difficult, but reduction in overall iterations is possible. Design depends upon the information flow within domain and also among various design disciplines and organizations. Therefore, it is suggested that managers should be aware about the crucial iterations causing rework and optimal sequence as well. In this way, managers can handle design parameters related to such iterations proactively. There are a number of techniques to reduce iterations for various kinds of engineering designs. In this paper, parameter based Design Structure Matrix (DSM) is chosen. To create this DSM, a survey was performed and then partitioned using a model. This paper provides an easy approach to those companies involved in or intend to be involved in "design and build projects."
\end{abstract}

Keywords : Design management, Construction, Information management, Model, Lean construction, Project management

\section{Introduction}

Iterations are unavoidable in design causing delays and chaos. On the other hand it is obligatory to produce design values. However, not all iterations generate value (Ballard 2000). But for efficient management we have to get rid of iterations that are not generating values or, at least have to reduce such iterations. There are many simple design cases in which the complete elimination of non-generative iterations is possible. But in case of complex design system such as construction, it is very rare. It is because of close interdependency regarding tremendous information flow between various professionals of different Design Subsystems (DS) and organizations. Besides the tremendous magnitude of information involve, the complexity with which this

\footnotetext{
* 일반회원, 한양대학교 건설환경공학과 석사, salmansalo@ @anyang.ac.kr

** 일반회원, 한양대학교 건설환경공학과 박사과정, kimjh0418@gmail.com

*** 일반회원, (주)한국종합기술 상무, 한양대학교 건설환경공학과 박사과정, jackpi@kecc.co.kr

***** 종신회원, 한양대학교 건설환경공학과 부교수, 공학박사, P.E(교신저자), jseo@ hanyang.ac.kr
} 
information flows contribute considerably to the difficulty of design (Gebala and Eppinger 1991). It is also a fact that construction design projects, particularly the design of roadway projects involve more design changes. And because of multidisciplinary nature rework can definitely occur.

Several techniques are available to reduce the nongenerative iterations as described by Ballard. The Design Structure Matrix (DSM) method is chosen as it can efficiently eliminate or reduce iterative loops by resequence design parameters/tasks. Much of research are focused on solving a complex design iteration using DSM (Tyson 2001, Mohammed et al. 2011, Benjamin and John 2009, Park et al. 2010). In addition to this, it is also helpful for finding an optimal sequence. The design is always an easy prey for internal and external uncertainties. Out-of-sequence design process leads to low productivity, prolonged duration, and decreased value of the design solution (Koskela et al. 1997). The application of matrices in design management of construction projects is not very common but for simulation or modeling it is widely acceptable. Moreover, complexity in design can be addressed using DSM based analysis model and is easily readable regardless of size. The use of matrices in system modeling can be traced back to Warfield in the $70^{\circ} \mathrm{s}$ and Steward in the $80^{\circ} \mathrm{s}$ (DSM Tutorial 2008). This paper addresses the resequence of the design parameters of various DS using DSM based analysis model. The purpose for putting emphasis on this approach and model is because the construction companies are now more involved in design and build based project to attain contractual integration. The emphasis is on making the managers proactive in design management by knowing the crucial iteration obtained, after reducing non-generative loops and getting optimal sequence. In this paper, we mainly address the harbor and the building design project to verifying DSM application to reduce iteration and acquire optimal sequence. The input data for the model was obtained through survey and workshop with table/spreadsheet from various managers/designer of design companies around.

\section{Design Structure Matrix}

\subsection{Di-graph and Adjacency Matrix}

In design phases, many of design parameters should be considered simultaneously. A di-graph (or directed graph) is a simple method to represent interconnection between those parameters. the di-graph is a collection of vertices, together with some arcs joining some of these vertices (Chen 2002). It can also be called as arrow diagram

$$
D=(V, A) \quad-------------------(1)
$$

where, $D=$ digraph

$$
\begin{aligned}
& V=\text { finite set or vertice } \\
& A=\text { a subject of Cartesian prouct } V \times V
\end{aligned}
$$

The adjacency matrix of the digraph $\mathrm{D}$ is an $\mathrm{n} \times \mathrm{n}$ matrix A where aij, the entry on the $\mathrm{i}$-throw and $\mathrm{j}$-th column is defined by

$$
a_{i j}=\left\{\begin{array}{l}
1 \text { if }(i, j) \in A \\
0 \text { if }(i, j) \notin A
\end{array}\right\}
$$

Figure 1 can also be expressed using Equation(1)

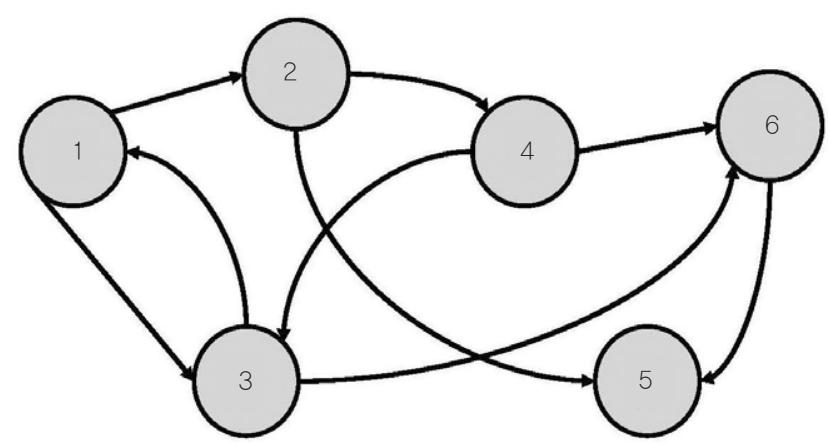

Figure 1. Diagraphs/Arrow Diagram of Matrix

$$
\begin{aligned}
V= & 1,2,3,4,5,6 \\
A= & (1,2),(1,3),(2,4),(2,5),(3,1), \\
& (3,6),(4,3),(4,6),(6,5)
\end{aligned}
$$

Adjacency matrix can be expressed using Equation (2) 


\section{$\begin{array}{llllllll}\text { Adjacency matrix } & \text { - } & \mathbf{1} & \mathbf{2} & \mathbf{3} & \mathbf{4} & \mathbf{5} & \mathbf{6}\end{array}$ \\ of Figure $1=\begin{array}{lllllll}\mathbf{1} & 0 & 1 & 1 & 0 & 0 & 0\end{array}$

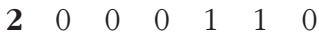 \\ $3 \quad 1 \quad 000010001$ \\ $4 \begin{array}{lllllll}4 & 0 & 0 & 1 & 0 & 0 & 1\end{array}$

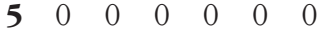 \\ 6}

\subsection{Design System Configuration}

Any design system is a result of interaction of its various subsystems' parameters or components. Relationship among these can be characterized by three fundamental building blocks; Parallel (independent), sequential (dependent), and coupled (interdependent), as shown in Figure 2.

In complex and large projects, the representation of interaction among various DS parameters is a difficult task. But DSM provides an easy and compact method to allocate and understand interaction. In design systems analysis, it is also called precedence matrix.

A precedence matrix is a square matrix with as many rows and as many columns as there are vertices in the graph (Steward 1981). DSM is a tool to eliminate or minimize iterative loops by resequence task. One major flaw of DSM is that it can not show every aspect of process model in a single view like a Gantt chart and an IDEFO (Integration DEFination Language 0) diagram. However, the DSM makes an excellent point of access for a user to the full data base of process information (Browning 2002).

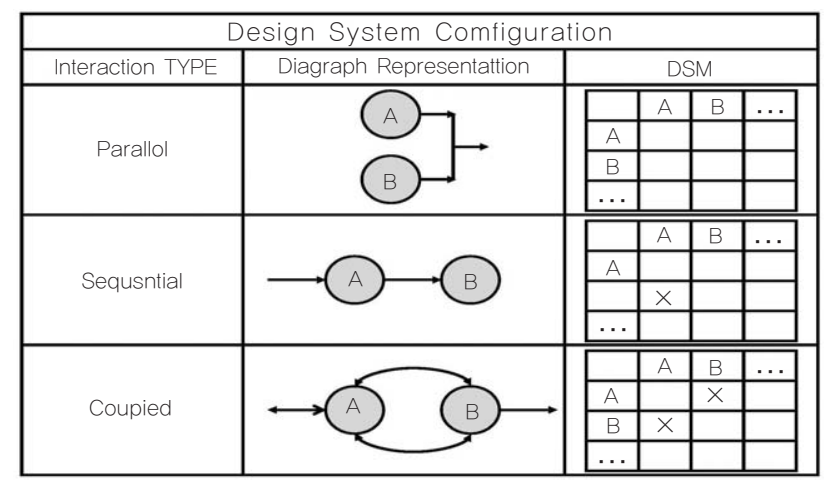

Figure 2. Interaction Types in Design
DSM configuration is as following: place down the design parameters/activities names on the left side of matrix as row headings and across the top of matrix as column headings in the same order (square matrix) as shown in Figure 3. The dependency of one parameter to other is represented by " $\mathrm{x}$ " or "1" marks in the offdiagonal cells. Otherwise it is left empty or assigned "0" mark. Usually the diagonal elements of DSM left empty or blackened-out. But for DSM analysis, where the binary numbers ( 0 and 1 only) involve, it should be zero. The dependency has to be read along the rows as "information required from" and along the columns as "information provided to."

DSM is a method to eliminate or minimize iterative loops by re-sequence of design parameters involved. Iterative loops can be identified by "x or 1" mark above the diagonal line of DSM. It depicts that information is required from downstream (later listed) parameter, and is called feedback mark. Similarly, such mark below the diagonal depicts that information will be transferred later, and is called feedforward mark. Feedback mark in Figure 3 depicts that design parameter (C) requires information from later parameter (D) and DSM is not in lower triangular form. The main objective of DSM method is to keep it in lower triangular form to obtain a sequence where each one can be executed only after it receives all information from its predecessors (Eppinger et al. 1993). But as described earlier that it may happen only in simple design project cases. Therefore, for large complex design projects it is suggested to keep feedback marks to a minimum and close to the diagonal line in order to get optimal sequence and crucial iterations.

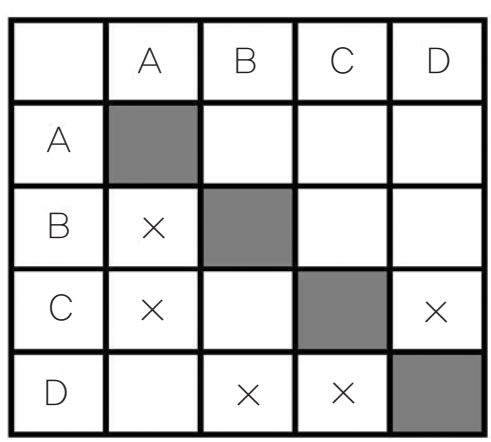

Figure 3. DSM Example 


\section{DSM analysis: partitioning and tearing}

DSM analysis implies the reordering of the given sequence resulting in optimal sequence including the crucial design parameters which require rework. It consists of partitioning and tearing algorithms (Steward 1965 and 1981).

\subsection{Partitioning Algorithm}

It is a process to reorder rows and columns of DSM in order to get a new sequence having no or least feedback marks. The partitioning algorithm is stated as following:

1. Identify the design parameters that require no information, which can be noted by observing empty rows in DSM. Separate such parameters from DSM (i.e. from rows and columns both) as high order design parameter in sequence. If more empty rows are found after separating then repeat this process until a DSM, having no empty row, is achieved.

2. Identify the design parameters that provide no information, which can be noted by observing empty columns in DSM. Separate such parameters from DSM (i. e. from columns and rows both) as low order design parameter in sequence. If more empty columns are found after separating then repeat this process until a DSM, having no empty column, is achieved.

3. If all design parameters have separated, then DSM is already partitioned after step 2. Otherwise, after completing step 1 and 2 or in cases where DSM has no empty rows and column then identify the loops causing rework.

\subsection{Identification of Loops by Powers of Adjacency Method:}

Loops in DSM can be identified using path searching method, powers of adjacency method, and reachability matrix method etc. In the proposed model the powers of adjacency method is used. This method involves taking the powers of DSM under consideration and then priority in the order is given to the parameters having least row sum. Take the powers of DSM until the matrix does not change or until the power matrix equal or exceeds the order of matrix (Steward 1962). In order to avoid the complexity of calculation Authors proposed to take the powers of DSM equal to the order of square matrix. During the process of taking powers of DSM the assigned dependency is also disturbed. The powers of Adjacency method consists of the following steps:

1. After separating high and low order parameters from the DSM obtained, make adjacency matrix by indicating the dependency mark '" and remaining cells including off-diagonal cells by assigning mark ' 0 .'

2. Take power of matrix (equal to order) by applying condition "value $>1=1$ " during multiplication.

3. Sum each row (design parameter) separately and arrange in increasing order.

4. Finally, to get the partitioned DSM, place design parameters related to loops between the high and low order design parameters obtained. Assign dependency to all design parameters as it was present in the DSM obtained before analysis.

In partitioned DSM, dependency of all parameters remains same, only the sequence changes. Figure 4 depicts the DSM Partitioning algorithm.

\subsection{Tearing Algorithm}

It is the process of further reordering of design parameters within the blocks of partitioned DSM. This process is applied because the design parameters partitioning provides the blocks/loops having two paths of entrance. Shunt diagram can be used for tearing purpose (Steward 1981). But this process entails both management and engineering judgment, and is extremely dependent upon the individual's knowledge of interrelationship (Warfield 1973). Therefore, it is suggested to limit the proposed model up to partitioning and leave the tearing upon the managers.

Then, managers can apply their knowledge to further reorder the blocks of partitioned DSM by keeping in view the lower triangular form. In addition to this, a survey can also be performed to rank the priority of design 


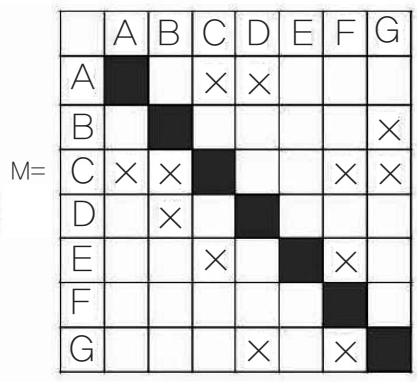

DSM obtained

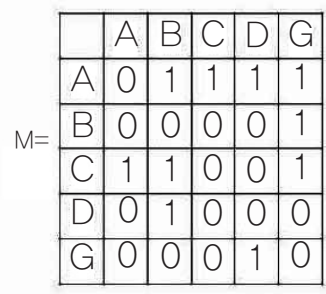

DSM before loops identification

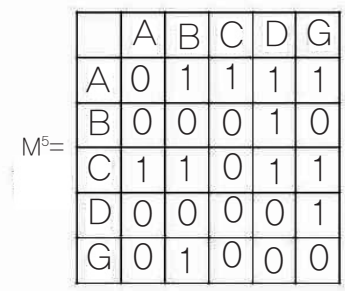

Loops identification by

powers Adjacency method

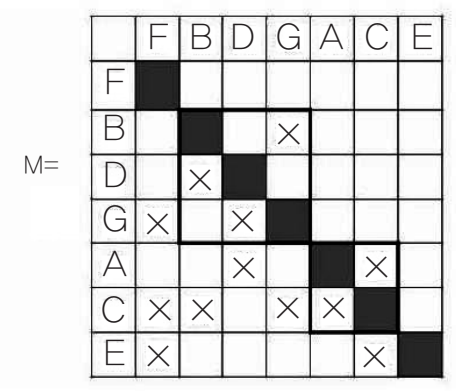

Partitioned DSM

High order design parameter is $F$

LOw order design parameter is $\mathrm{E}$

Parameters dependency is present above dingonal

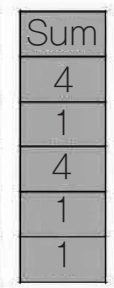

Crucial Iterations/blocks: BDG \& AC Most of Paramcters dependency is present below diagonal

Figure 4. DSM Partitioning by Powers of Adjacency Method

1. Place the design parameter at the top within block having empty/minimum input requirement by observing partitioned DSM rows.

2. If more than one such parameter is found then determine which one delivers maximum output by observing partitioned DSM column, and schedule it first.

3. Repeat the process till all loops are scheduled.

4. If it is still not possible to order within blocks then arrange the design parameters, keeping in view the required result, to form lower triangular matrix having no feedback marks or try to schedule to get dependency close to diagonal line.

\section{Proposed Model and Case Study}

\subsection{Research Methodology and Model Algorithm}

The research methodology involves the survey and workshop from engineers/mangers to make DSM and then input into the model engine to obtain the results. The compilation of results provides a required Partitioned DSM. Figure 5 depicts the research methodology adopted along with the algorithm of proposed model. The idea of survey was conceived from Massachusetts Institute of Technology (MIT) DSM research team (DSM Tutorial 2012). Almost 20 surveys have been performed, which include building, sewer, bridge, and harbor design projects. This survey was based on three questions as indicated in Figure 5. In order to check the veracity of proposed model, it was applied to nearly all examples of reference papers.

\subsection{Implementation on Harbor and Building Ddesign}

Although DSM has a wide range of applications, but for construction point of view the DSM methodology is not very common. The construction design projects like harbor and roadway are frequently subjected to sudden changes in design, even during the construction phase. Hence, the harbor design project has been chosen for one of implementation examples. On the basis of survey and workshop with 5 different Table 1, the DSM is obtained and loaded. The complete operation to use DSM interface is shown in Figure 6. 
Table 1. Survey Results of Harbor Design Project

\begin{tabular}{|c|c|c|c|}
\hline $\begin{array}{c}\text { Design } \\
\text { Para- } \\
\text { meter Code }\end{array}$ & Design Parameter & $\begin{array}{c}\text { Required } \\
\text { Design } \\
\text { Parameter }\end{array}$ & $\begin{array}{l}\text { Design } \\
\text { Sub- } \\
\text { system }\end{array}$ \\
\hline 1 & Decision of vessel types & & \multirow{5}{*}{$\begin{array}{l}\text { Design } \\
\text { condition } \\
\text { (D) }\end{array}$} \\
\hline 2 & wind pressure & & \\
\hline 3 & wave & & \\
\hline 4 & wave force & & \\
\hline 5 & tides & & \\
\hline 6 & types of breakwater structure & $2,3,4,5$ & \multirow{6}{*}{$\begin{array}{l}\text { Counter } \\
\text { facilities } \\
\text { Design } \\
\text { (C) }\end{array}$} \\
\hline 7 & breakwater section decision & $6,8,9,10$ & \\
\hline 8 & breakwater exterior force calculation & $2,3,4,5$ & \\
\hline 9 & breakwater stability calculation & $2,3,4,5,7$ & \\
\hline 10 & breakwater member design & 8 & \\
\hline 11 & revetment design & $2,3,4,5$ & \\
\hline 12 & gravity quay wall design & $1,2,3,4,5$ & \multirow{8}{*}{$\begin{array}{l}\text { Mooring } \\
\text { facility } \\
\text { design } \\
\text { (M) }\end{array}$} \\
\hline 13 & pier quay wall design & $1,2,3,4,5$ & \\
\hline 14 & tie rod sheet pile quay wall design & $1,2,3,4,5$ & \\
\hline 15 & lathe sheet pile quay wall design & $1,2,3,4,5$ & \\
\hline 16 & cell type sheet pile quay wall design & $1,2,3,4,5$ & \\
\hline 17 & steel sheet pile design & $1,2,3,4,5$ & \\
\hline 18 & floating pier design & $1,2,3,4,5$ & \\
\hline 19 & dolphin design & $1,2,3,4,5$ & \\
\hline 20 & ocean lane & 1 & \multirow{4}{*}{$\begin{array}{c}\text { water } \\
\text { facilities } \\
\text { design (W }\end{array}$} \\
\hline 21 & mooring basin & 1 & \\
\hline 22 & turning basin & 1 & \\
\hline 23 & small diurnal range & 1 & \\
\hline 24 & dredging soil calculation & & \multirow{5}{*}{$\begin{array}{l}\text { Dredging } \\
\text { and } \\
\text { reclam- } \\
\text { ation } \\
\text { (R) }\end{array}$} \\
\hline 25 & dredger and dredging methods & 24 & \\
\hline 26 & dredging capacity & 24,25 & \\
\hline 27 & disposal place of dredged soil & $24,25,26$ & \\
\hline 28 & reclamation method of reclaimed soil & & \\
\hline 29 & marina water facilities & $1,2,3,4,5$ & \multirow{4}{*}{$\begin{array}{l}\text { Marina } \\
\text { design } \\
\text { (A) }\end{array}$} \\
\hline 30 & marina counter facilities & $1,2,3,4,5$ & \\
\hline 31 & marina mooring facilities & $1,2,3,4,5$ & \\
\hline 32 & marina safety facilities & $1,2,3,4,5$ & \\
\hline 33 & navigation system design and analysis & & \multirow{5}{*}{$\begin{array}{l}\text { Aids to } \\
\text { navigation } \\
\text { facility } \\
\text { design } \\
\text { (N) }\end{array}$} \\
\hline 34 & light house and light pole & & \\
\hline 35 & pilotage and leading lights & & \\
\hline 36 & beacon lighting buoy and buoy & & \\
\hline 37 & bridge marks on sea & & \\
\hline
\end{tabular}

The Partitioned DSM of harbor design project offered the optimal sequence along with one crucial iteration of design parameters. The apartment building design project survey data are also shown in Table 2, and Partitioned DSM of it is shown in figure 7.

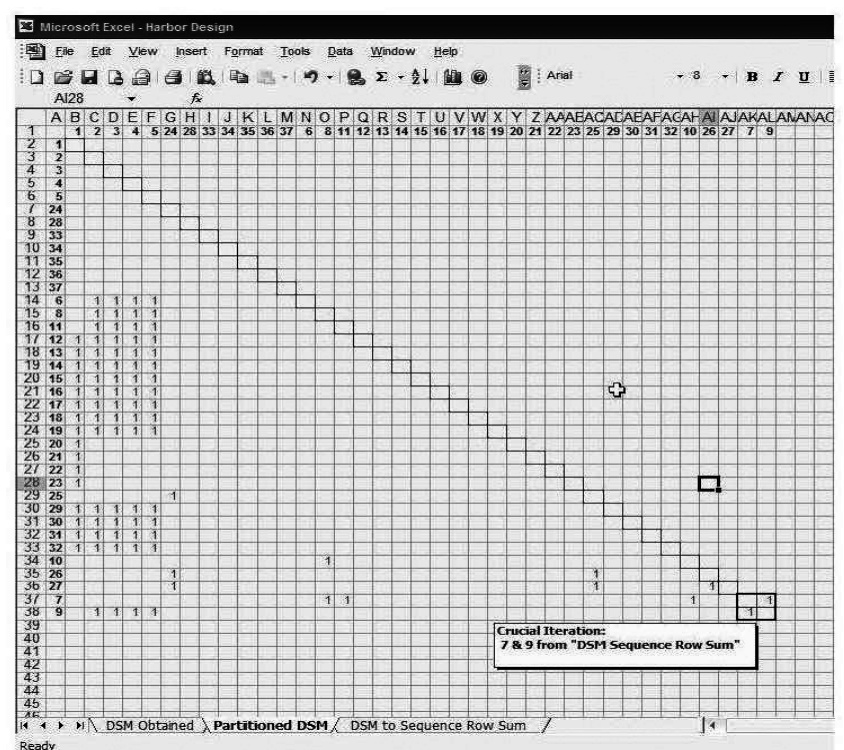

Figure 6. The Complete Operation Using Dsm Interface

Table 2. Survey Results of Building Design Project

\begin{tabular}{|c|c|c|c|}
\hline $\begin{array}{c}\text { Design } \\
\text { Para- } \\
\text { meter Code }\end{array}$ & Design Parameter & $\begin{array}{l}\text { Required } \\
\text { Design } \\
\text { Parameter }\end{array}$ & $\begin{array}{l}\text { Design } \\
\text { Sub- } \\
\text { system }\end{array}$ \\
\hline 1 & Project site & & \multirow{20}{*}{$\begin{array}{c}\text { Architec- } \\
\text { types } \\
\text { Design } \\
\text { (A) }\end{array}$} \\
\hline 2 & Building coverage & 4 & \\
\hline 3 & Floor area ratio(FAR) & $2,4,5$ & \\
\hline 4 & Maximum total floor area & $2,3,5$ & \\
\hline 5 & Maximum number of story & 3,4 & \\
\hline 6 & Parking lot & & \\
\hline 7 & Direction & 8 & \\
\hline 8 & Landscape & 7 & \\
\hline 9 & Car traffic line & $57,58,59,60$ & \\
\hline 10 & Pedestrian traffic line & 54 & \\
\hline 11 & Types of residence construction & $3,4,7,8$ & \\
\hline 12 & Scale of community facility & 4 & \\
\hline 13 & Scale of neighborhood facility & 4 & \\
\hline 14 & Rank of rooms according to the type/uses & 11,15 & \\
\hline 15 & Size of room & 11 & \\
\hline 16 & Size of air handling unit room & 32 & \\
\hline 17 & Size of evacuation space & 11 & \\
\hline 18 & Standards of boundary wall installation & 15 & \\
\hline 19 & Ceiling height & 15 & \\
\hline 20 & Floor level(bathroom, balcony, room) & $11,14,33,34$ & \\
\hline 21 & Indoor Varnish & & \multirow{11}{*}{$\begin{array}{c}\text { Interior } \\
\text { Design (Int) }\end{array}$} \\
\hline 22 & Furniture & 19 & \\
\hline 23 & Home appliance & 19 & \\
\hline 24 & Door & 19 & \\
\hline 25 & Balcony window & 19 & \\
\hline 26 & Thickness of insulation wall and its position & $27,28,29,30,31$ & \\
\hline 27 & Size of beam and position & $26,28,29,30,31$ & \\
\hline 28 & Size of column and position & $26,27,29,30,31$ & \\
\hline 29 & Structure open part reinforcement & 27,28 & \\
\hline 30 & Weight of household & $26,27,28,29$ & \\
\hline 31 & Column space underground structure & $26,27,28,29,30$ & \\
\hline
\end{tabular}


Table 2. Survey Results of Building Design Project

\begin{tabular}{|c|c|c|c|}
\hline $\begin{array}{c}\text { Design } \\
\text { Para- } \\
\text { meter Code }\end{array}$ & Design Parameter & $\begin{array}{c}\text { Required } \\
\text { Design } \\
\text { Parameter }\end{array}$ & $\begin{array}{l}\text { Design } \\
\text { Sub- } \\
\text { system }\end{array}$ \\
\hline 32 & $\begin{array}{l}\text { Position of external part of air } \\
\text { conditioner \& plumbing }\end{array}$ & 16 & \multirow{8}{*}{$\begin{array}{c}\text { Mechanical } \\
\text { (M) }\end{array}$} \\
\hline 33 & Position of sprinkler & 19 & \\
\hline 34 & Heating pipes design & 20 & \\
\hline 35 & Gas supply plumbing & & \\
\hline 36 & Gas detecting system design & & \\
\hline 37 & Hot water header & 22 & \\
\hline 38 & Machine room instrument design & & \\
\hline 39 & Cooling and heating & 12,13 & \\
\hline 40 & Light design & 19 & \multirow{5}{*}{$\begin{array}{l}\text { Electrical } \\
\text { Design (E) }\end{array}$} \\
\hline 41 & Electric heat design & 23 & \\
\hline 42 & Distribution board design & $21,22,23$ & \\
\hline 43 & Communication design & & \\
\hline 44 & Receptacle design & 21,22 & \\
\hline 45 & Sanitary sewer plumbing & 46,48 & \multirow{5}{*}{$\begin{array}{l}\text { Infrastructure } \\
\text { Design (Inf) }\end{array}$} \\
\hline 46 & Storm-water plumbing & $9,10,45,48$ & \\
\hline 47 & Retaining wall & 49 & \\
\hline 48 & Water pipe pluming & 45,46 & \\
\hline 50 & Soil investigation & $47,49,51,52$ & \\
\hline 51 & Landslide protection design & 49,50 & $\begin{array}{l}\text { Temporary } \\
\text { Structure } \\
\text { Design(T) }\end{array}$ \\
\hline 52 & Drainage design of ground-water & $49,50,51$ & $\operatorname{lnf}$ \\
\hline 53 & Planting design & 54 & $\begin{array}{l}\text { Landscape } \\
\text { Design (L) }\end{array}$ \\
\hline 54 & Pavement design & 53 & \multirow{4}{*}{$\begin{array}{c}\text { Traffic Affects } \\
\text { Assessment } \\
(T r .)\end{array}$} \\
\hline 55 & External environment facility design & & \\
\hline 56 & Retaining wall design & 47,49 & \\
\hline 57 & Car traffic line analysis & 9,10 & \\
\hline 58 & traffic signal design & 9 & \multirow{4}{*}{$\begin{array}{c}\text { Environmental } \\
\text { Affect } \\
\text { Assessment } \\
\text { (En) }\end{array}$} \\
\hline 59 & Composition of roads & 9,10 & \\
\hline 60 & Pedestrian crossing design & 9,10 & \\
\hline 61 & Environmental-friendly structure design & & \\
\hline
\end{tabular}

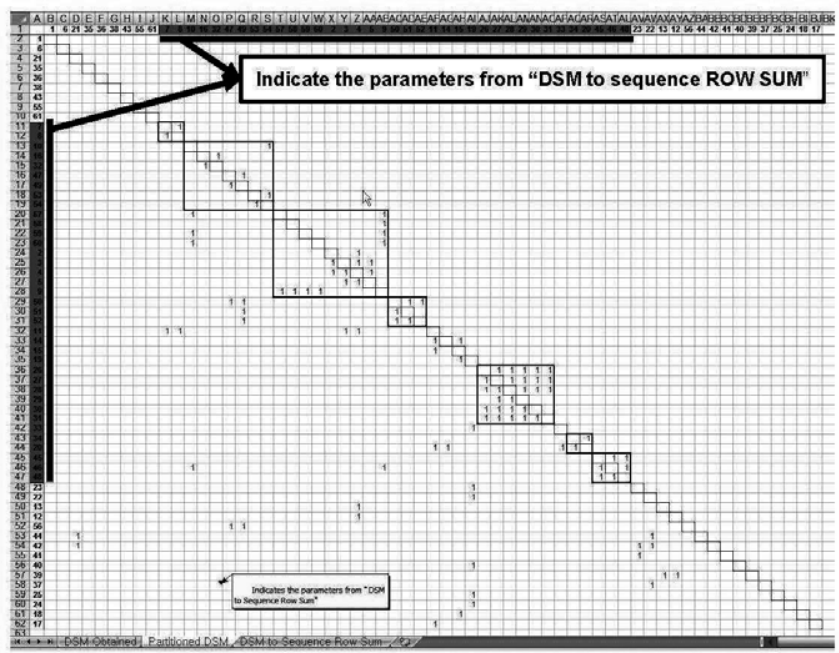

\section{CONCLUSION}

The significance of information flow in design is widely acceptable but the multidisciplinary nature of design always causes hindrance in it due to iterations. The emerging corporate trend in construction is also causing multifarious problems regarding responsibility measures. The optimal sequence and lessen the rework have been a challenging task for managers. The DSM has the capability to represent the information requirements of complex design projects and is a tool to get crucial iterations and optimal sequence. Its combination with Critical Path Method (CPM) and use of numeric DSM may also lead to technical and managerial benefits. In the proposed model, compilation of results causes some time delays to the user but the model is an effective tool to obtain required results. The proposed model not only facilitates the managers to manage the iterations proactively but also illustrates to software systems for design management. The survey data can also be utilized as regional trend about design management. The more involvement of construction companies is still suggested so that real situation can be exposed. It is also suggested to organize mutual sessions of construction managers and designers to sort out problems and to form effective design management software. For further research, Authors proposed to establish a parameter based designer interfaces model to input dependency and then after formation of basic sequence any future change can be saved and propagated to all participants in a collaborative environment. 


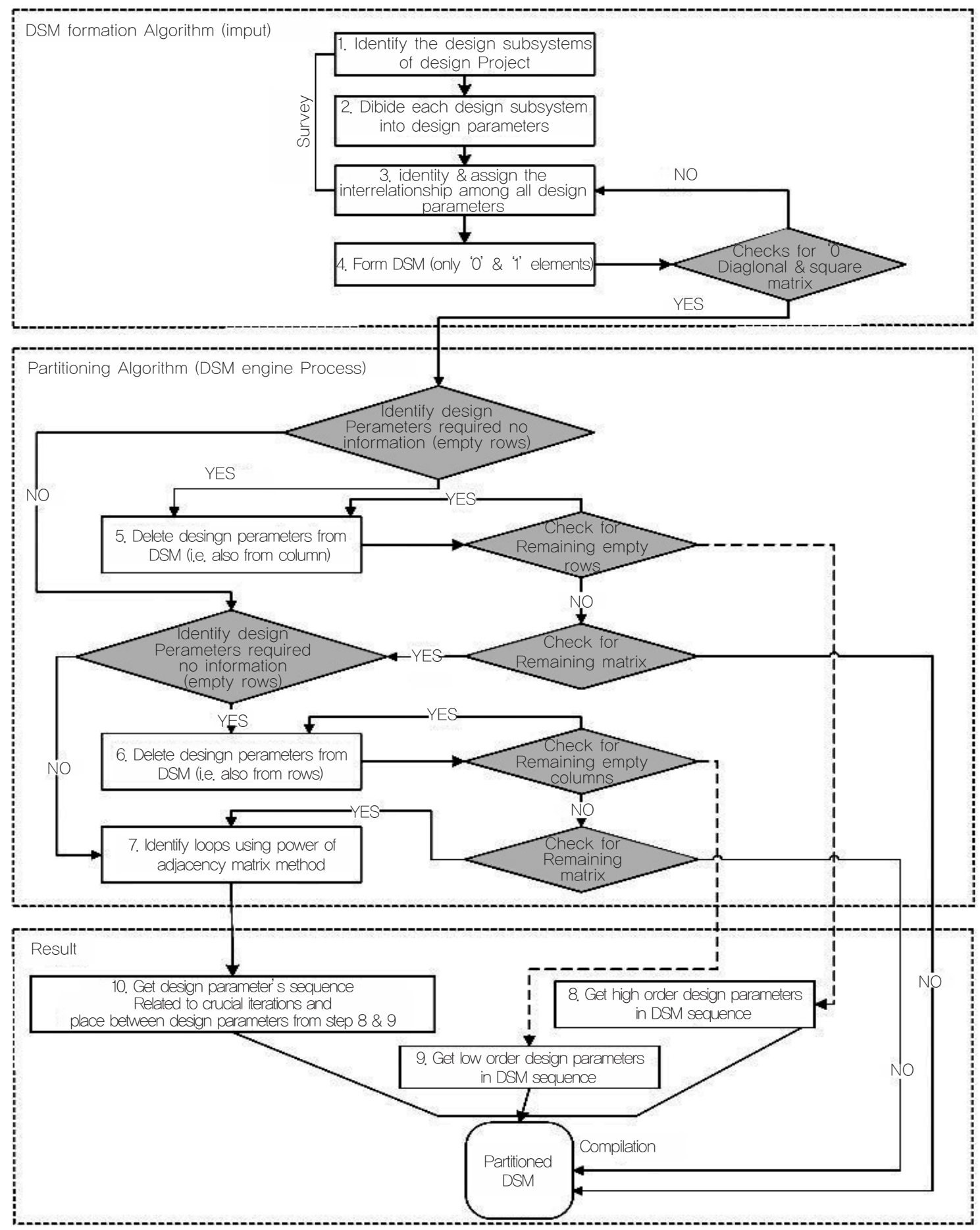

Figure 5. Proposed Model Methodology and Algorithm

\section{References}

Ballard, G. (2000). "Positive vs. negative iterations in design" Proceedings Eighth Annual Conference of the International Group for Lean Construction, IGLC-6, Brighton, UK, July 17 19.
Benjamin B. and John S. (2009). "Application of the Design Structure Matrix (DSM) to the Real Estate Development Process", Cemter for Real Estate in MIT.

Browning, T. R. (2002). "Process Integration using the design structure matrix." System Engineering: The 
journal of the International Council on System Engineering, 5(3), pp.180 193.

Chen, WW L. (2002). "Chapter 20-Diagraphs." Discrete mathematics.

DSM Tutorial (2012), “Technical DSM Tutorial”, $\langle$ http://www.dsmweb.org (2012. 9. 3).

Eppinger, S. D., Whitney, D. E., Smith, R. P., and Gebala, D.A. (1993). "A model-based method for organizing tasks in product development., , MIT, WP\# 3569-93-MS.

Gebala, D.A. and Eppinger, S. D. (1991). "Methods for analyzing design procedures." DE- Vol.31, Design theory and Methodology ASME.

Kim J., Kim K., and Han J. (2011). "An Administration Model for Causes of Delay in Construction Projects to Decide Time Extension Responsibility", Korean Journal of Construction Engineering and Management, 2(6), pp.31 41.

Koskela, L., Ballard, G., and Tanhuanpaa, V. (1997). "Towards lean design management." Proceedings 5th Annual Conference of the International Group for Lean Construction, Griffith University, Gold Coast, Australia, July.

Mohammed O., Nadia B., and Linghua K., (2011). "Application of the Design Structure Matrix to Wheelchair Development", Proceedings of the 2011 International Conference on Industrial Engineering and Operations Management, Kuala Lumpur, Malaysia, January 22?24, 2011, pp.583 588
Park, M., Ham, Y., Lee, H. and Kim, W. (2010). "Development of Design Process Management Model using Dependency Structure Matrix for constructability", Korean Journal of Construction Engineering and Management, 11(5), pp.65 74.

Steward, D.V. (1962). "On an approach to technique for the analysis of the structure of large systems of equations." SIAM Review, 4(4), pp.321 342.

Steward, D.V. (1965). "Partitioning and tearing system of equation." Journal of the society for industrial and applied mathematics: Series B, Numerical Analysis, 2(2), pp. 345 365.

Steward, D.V. (1981). "System analysis and management: structure, strategy, and design.” Petrocelli Books, NewYork,

Warfield, J. N. (1973). "Binary matrices in system Modeling, IEEE transaction, man, and cybernetics, Vol. SMC-3, No.5

Tyson, R. B. (2001). "Applying the Design Structure Matrix to System Decomposition and Integration Problems: A Review and New Directions", IEEE transactions on engineering management, 48(3), pp. 292 306.

논문제출일: 2011.08.09 논문심사일: 2011.08.12 심사완료일: 2012.11.14 